\title{
Research Paper: Environmental Health and Safety Assessment of Schools in Khalkhal City Using Crisis Management Approach
}

\author{
Mehdi Vosoughi $^{1}$, Abdollah Dargahi ${ }^{*}$,, Parvin Teymouri $^{2}$ \\ 1. Department of Environmental and Occupational Health, Social Determinants of Health Research Center, Ardabil University of Medical Sciences, \\ Ardabil, Iran. \\ 2. Department of Environmental Health Engineering, School of Health, Khalkhal University of Medical Sciences, Khalkhal , Iran.
}

\begin{tabular}{|l|l|l}
\hline $\begin{array}{c}\text { Use yourdevic to scan } \\
\text { and read the article online }\end{array}$ & $\begin{array}{l}\text { ing Crisis Management Approach. Health in Emergencies and Disasters Quarterly. 2019; 5(2):91-98. http://dx.doi.org/10.32598/ } \\
\text { hdq.5.2.189.13 }\end{array}$ \\
dof http://dx.doi.org/10.32598/hdq.5.2.189.13
\end{tabular}

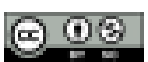

Article info:

Received: 06 Sep 2018

Accepted: 10 Oct 2019

Available Online: 01 Jan 2020

\section{Keywords:}

Environmental health, School health, Safety, Crisis management

\section{ABSTRACT}

Background: Paying attention to physical, health and safety issues in educational environments is the most effective and fundamental factor for physical, mental and psychological development of students. Therefore, one of the most important and effective health issues of the school is to observe environmental health and safety. This study was conducted with the aim of surveying the environmental health and safety of schools in Khalkhal city with a crisis management approach.

Materials and Methods: This is a descriptive study with cross sectional design. The study population consists of all primary, middle and high schools in Khalkhal city $(n=28)$. For sampling, census method was used. Data collection tool was an 87-item checklist that surveys the health status of schools and its classrooms in terms of health and safety facilities. It was completed by visiting schools and observing, interviews and measurements. Collected data were analyzed in SPSS and Excel software.

Results: $10 \%$ of schools had newly constructed buildings and $90 \%$ had old buildings. The minimum required area per student was observed in all schools. The green space area required for each student is 0.5 square meters, which was not observed in $73.83 \%$ of schools. Only $87.5 \%$ of schools had one toilet for every 40 students. Sewage disposal in $98 \%$ of schools was hygienic, and $100 \%$ of schools had sanitary trash cans. In $60 \%$ of the schools, the toilets did not meet the hygiene standards. In $84 \%$ of the schools, the number of washbasins was proportional to the number of students ( 1 per 60$)$. All the classrooms had maximum use of natural light. Moreover, in most schools, health policies, safety policies and emergency and personal hygiene standards were met.

Conclusion: Most schools in Khalkhal city were at moderate level in terms of environmental health and safety and compliance with national school environmental health regulations as well as being prepared to deal with emergencies and crises which indicates a need for more attention and support from the relevant authorities for improving their status.

\footnotetext{
* Corresponding Author: Abdollah Dargahi, PhD.

Address: Department of Environmental and Occupational health, Research Center Social Determinants of Health Research Center, Ardabil University of Medical Sciences, Ardabil, Iran.

E-mail: a.dargahi29@yahoo.com
} 


\section{Introduction}

A

Child's world is made up of home, school, and the community around him/her. These places should be designed to meet the physical, mental, and social needs of students. In modern education, physical space is considered as a living and dynamic factor in students' educational activities [1]. Paying attention to physical, health and safety issues in educational environments is the most effective and fundamental factor of physical and mental growth and learning in students [2]. Therefore, one of the most important and effective health issues of the school is to observe environmental health and its safety. School environment health refers to the control of factors in students' living environment that affect their physical, mental and social well-being and has a direct effect on preventing the transmission of diseases and improving the health of school environment [3].

Students may develop a variety of parasitic, infectious diseases and diarrheal if the principles of environmental health and school safety are not followed [4]. Studies show that $59 \%$ of students are infected with intestinal parasites and $29.5 \%$ with monocytes. If school safety is not at an acceptable level, students will be more likely to have accidents, injuries, and deaths [5], and if school ergonomic standards are not met, it will lead to fatigue and skeletal and muscular pains [6]. Therefore, there must be safety-related and emergency-related procurements and precautions in place at schools; children's presence should be controlled as well as their arrival and departure to ensure their maximum safety; nutrition time should be considered as learning time, and personal hygiene should be part of the curriculum [7].

The most important factors that reduce the level of environmental health, safety and ergonomics in schools include: insufficient educational space, proximity of schools to unsanitary and unsafe places, old school building, unhygienic conditions of toilets and drinking fountains, unsanitary and unsafe classrooms and school grounds, risk of electric shock and fire, insufficient first aid facilities, and unsuitable board, desk and bench for students $[8,9]$. Therefore, having a comprehensive crisis management program constantly prepares principals to confront the crisis threatening their schools, thereby reducing its impact while preventing it and saving schools from the vortex of various crises in a way that they suffer the least damage [10]. Assessing the current state of schools is the first step in preventing crisis in them, and on the other hand, evaluation and assessment is a part of the effectiveness of systems [11].
In one study, it was found that children's injuries in schools are a major concern and special attention should be paid to specific areas in schools in order to prevent accidents [12]. In a study conducted by Kumar et al. (2008), it was found that there is a direct relationship between physical characteristics of schools and students' behavioral problems [13]. According to statistics released in the United States in 1990, about 43\% of children's mental and emotional problems were related to schools, of which $20 \%$ were because of schools' buildings [12]. Given the importance of crisis management in schools and the role of assessing the current situation in crisis prevention and control in schools, this study aimed to Investigate the environmental health and safety situation of schools in Khalkhal city, Iran with crisis management approach by measuring the conditions of toilets, washbasins and drinking fountains, location of garbage and sewage collection, and health and safety of classrooms.

\section{Materials and Methods}

This is a descriptive study with cross sectional design conducted in 2015. The study population consists of all primary, middle and high schools in Khalkhal City $(n=28)$. Khalkhal is one of the cities of Ardabil Province with a relatively cold climate. This city is connected from the north to Kowsar County, from the east to Guilan province, from the south to Tarom city in Zanjan province, and from the west to Miyaneh County. For sampling, census method was used. Data collection tool was an 87-item checklist that surveys the health status of schools in terms of health and safety facilities, the health status of school classrooms in terms of health facilities and safety, and the safety status of school laboratories. It was completed by visiting schools and observing, interviews and measurements. Collected data were analyzed in SPSS and Excel. It should be noted that the checklist has acceptable validity designed based on the school environmental health regulations of the Iranian Ministry of Health and other scientific sources and was prepared and finalized by the research team.

\section{Results}

The results of evaluating the health status of schools based on health facilities (water, drinking fountains, toilets, washbasins, sewage disposal, buffet, health service room, and distance from annoying centers and unsanitary places) are shown in Table 1; based on safety of the classrooms, hallways, stairs, laboratories and school grounds in Table 2; based on health and safety facilities (classrooms' lights, blackboards, wall painting, space, dimension, windows, etc.) in Table 3; and based 
Table 1. The health status of schools in Khalkhal based on their health facilities

\begin{tabular}{|c|c|c|c|c|}
\hline \multirow{2}{*}{ Facilities } & \multirow{2}{*}{ Parameters } & \multicolumn{2}{|c|}{ No. (\%) } & \multirow{2}{*}{ Total } \\
\hline & & Healthy & Unhealthy & \\
\hline \multirow{2}{*}{ Water } & Piped water supply system & $28(100)$ & $0(0)$ & 28 \\
\hline & Having quality water approved by health authorities & $28(100)$ & $0(0)$ & 28 \\
\hline \multirow{7}{*}{ Drinking fountains } & Having washable surface with a suitable slope & $19(85.67)$ & $9(14.32)$ & 28 \\
\hline & Having washable wall & $19(85.67)$ & $9(14.32)$ & 28 \\
\hline & Proper edge & $19(85.67)$ & $9(14.32)$ & 28 \\
\hline & Existence of 1 for every 45 students & $13(42.46)$ & $15(57.53)$ & 28 \\
\hline & Separation from toilets & $12(85.42)$ & $16(14.57)$ & 28 \\
\hline & Standard wastewater disposal & $28(100)$ & $0(0)$ & 28 \\
\hline & Height between $75-100 \mathrm{~cm}$ above ground level & $24(71.85)$ & $4(28.14)$ & 28 \\
\hline \multirow{5}{*}{ Washbasins } & Existence of 1 for every 60 students & $14(50)$ & $14(50)$ & 28 \\
\hline & Having hygienic conditions & $21(75)$ & $7(25)$ & 28 \\
\hline & & & & \\
\hline & Having liquid soap & $27(43.96)$ & $1(57.3)$ & 28 \\
\hline & Height proportional to the age of students & $27(43.96)$ & $1(57.3)$ & 28 \\
\hline \multirow{5}{*}{ Toilets } & Existence of 1 for every 40 students & $22(57.78)$ & $6(43.21)$ & 28 \\
\hline & Having hygienic conditions & $24(71.85)$ & $4(19.14)$ & 28 \\
\hline & & & & \\
\hline & Standard sewage disposal & $28(100)$ & $0(0)$ & 28 \\
\hline & Suitable septic tank size & $28(100)$ & $0(0)$ & 28 \\
\hline \multirow{5}{*}{ Buffet } & $\begin{array}{c}\text { Observance of Article } 13 \text { of the Iranian food, cosmetics } \\
\text { and health products law }\end{array}$ & $18(75)$ & $6(25)$ & 24 \\
\hline & Floor, wall and ceiling made of durable materials & $5(8.20)$ & $19(2.79)$ & 24 \\
\hline & Seamless and washable & $5(8.20)$ & $19(2.79)$ & 24 \\
\hline & $\begin{array}{c}\text { Made of stone or tile with an height of } 1.30 \mathrm{~m} \text { and a light } \\
\text { color }\end{array}$ & $5(8.20)$ & $19(2.79)$ & 24 \\
\hline & Buffet staff have a valid medical examination certificate & $14(3.58)$ & $10(7.41)$ & 24 \\
\hline \multirow{2}{*}{ Sewage disposal } & Sanitary trash cans & $28(100)$ & $0(0)$ & 28 \\
\hline & Observance of the time interval between disposals & $27(4.96)$ & $1(6.3)$ & 28 \\
\hline \multirow{3}{*}{ Health service room } & Equipped health service room & $4(7.85)$ & $24(3.14)$ & 28 \\
\hline & Presence of a health coach & $11(3.39)$ & $17(7.60)$ & 28 \\
\hline & Existence of first aid kit & $28(100)$ & $0(0)$ & 28 \\
\hline $\begin{array}{l}\text { Distance from an- } \\
\text { noying centers and } \\
\text { unsanitary places }\end{array}$ & $\begin{array}{l}\text { Factory, landfill, cemetery, slaughterhouse, livestock, } \\
\text { poultry, noisy centers, hospital }\end{array}$ & $28(100)$ & $0(0)$ & 28 \\
\hline
\end{tabular}


Table 2. The health status of schools in Khalkhal based on their safety facilities

\begin{tabular}{|c|c|c|c|c|}
\hline \multirow{2}{*}{ Facilities } & \multirow{2}{*}{ Parameters } & \multicolumn{2}{|c|}{ No. (\%) } & \multirow{2}{*}{ Total } \\
\hline & & Healthy & Unhealthy & \\
\hline \multirow{9}{*}{$\begin{array}{l}\text { Classrooms and } \\
\text { hallways }\end{array}$} & Minimum ceiling height ( 3 meters) & $24(71.85)$ & $4(29.14)$ & 28 \\
\hline & $\begin{array}{l}\text { Upper-floor windows are equipped with a safety } \\
\text { fence }\end{array}$ & $4(05.21)$ & $15(95.78)$ & $19^{*}$ \\
\hline & Lighting (100-150 lux) & $28(100)$ & $0(0)$ & 28 \\
\hline & Temperature $\left(18-21^{\circ} \mathrm{C}\right)$ & $28(100)$ & $0(0)$ & 28 \\
\hline & Humidity (50-60\%) & $25(28.89)$ & $3(72.10)$ & 28 \\
\hline & Suitable ventilation system & $25(28.89)$ & $3(72.10)$ & 28 \\
\hline & Use of artificial light in evening classes (200-500 lux) & $6(100)$ & $0(0)$ & $6^{* *}$ \\
\hline & $\begin{array}{l}\text { Prohibition of building any terrace and balcony } \\
\text { related to the classrooms }\end{array}$ & $24(71.85)$ & $4(29.14)$ & 28 \\
\hline & Observing safety rules for cooling and heating devices & $28(100)$ & $0(0)$ & 28 \\
\hline & Non-slip and equipped with handholds & $24(71.85)$ & $4(29.14)$ & 28 \\
\hline Stairs & $\begin{array}{c}\text { Maximum height }(18 \mathrm{~cm}) \text {, minimum width }(30 \mathrm{~cm}) \\
\text { and minimum length }(1.20 \mathrm{~cm})\end{array}$ & $26(86.92)$ & $2(14.7)$ & 28 \\
\hline Laboratory & Existence of safety instructions & $9(47)$ & $8(53)$ & $17^{* * *}$ \\
\hline \multirow{3}{*}{$\begin{array}{l}\text { Fire extinguish- } \\
\text { ing system }\end{array}$} & Equipped with fire extinguishers & $26(86.92)$ & $2(14.7)$ & 28 \\
\hline & Existence of at least 2 emergency exits & $16(15.57)$ & $12(85.42)$ & 28 \\
\hline & Existence of emergency alarm & $25(28.89)$ & $3(72.10)$ & 28 \\
\hline \multirow{4}{*}{ School grounds } & Prohibition of building any pool or pond in the school & $27(42.96)$ & $1(58.3)$ & 28 \\
\hline & 0.5 square meters of green space per student & $8(57.28)$ & $20(43.71)$ & 28 \\
\hline & Grounds with suitable material (asphalt or concrete) & $28(100)$ & $0(0)$ & 28 \\
\hline & $6-8$ square meters of ground per student & $25(29.89)$ & $3(72.10)$ & 28 \\
\hline
\end{tabular}

* 19 schools had safety fences classified as healthy and unhealthy; **6 schools had evening classes; ***17 schools had laboratories

on laboratory safety status (floor and surface conditions, washability, non-slip floor with suitable slope, having air conditioner appropriate to its space, having toilet and liquid soap, and existence of safety instructions) in Table 4.

\section{Discussion}

This study was conducted to investigate the situation of environmental health and safety in schools of Khalkhal City with a crisis management approach. All of the schools were at least 500 meters away from places such as landfills, hospitals, factories, high-voltage power lines, livestock farms, poultry farms, and noisy cen- ters. In all schools, the method of sewage disposal was hygienic, and the volume and capacity of septic tanks were proportional to the user population. The results of a study by Lee et al. on 9 schools in China showed that increasing school health could lead to improved healthy behaviors and increased self-care among students [14] According to school environmental standards and regulations, there should be at least one drinking fountain for every 45 students, one toilet for every 40 students, and one washbasin for every 60 students [15].

All schools in Khalkhal had sanitary trash cans and in $96.4 \%$ of them, the time interval between emptying and washing the trash cans was observed. $46.42 \%$ of schools 
Table 3. The health status of schools in Khalkhal based on their health and safety facilities

\begin{tabular}{|c|c|c|c|}
\hline \multirow{2}{*}{ Health and Safety Facilities } & \multicolumn{2}{|c|}{ No. (\%) } & \multirow{2}{*}{ Total } \\
\hline & Healthy & Unhealthy & \\
\hline Dry, smooth, and seamless walls & $18(28.64)$ & $10(72.35)$ & 28 \\
\hline Washability of the wall up to a height of $1.2 \mathrm{~m}$ & $17(71.60)$ & $11(29.39)$ & 28 \\
\hline Washable floor with suitable slope & $27(43.96)$ & $1(57.3)$ & 28 \\
\hline Smooth and seamless ceiling in bright colors & $22(51.78)$ & $6(43.21)$ & 28 \\
\hline $\begin{array}{l}\text { Minimum distance from the blackboard to the first row of stu- } \\
\text { dent desks ( } 2.2 \text { meters) }\end{array}$ & $25(29.89)$ & $3(71.10)$ & 28 \\
\hline Maximum classroom size $(7 \times 8 \mathrm{~m})$ & $24(71.85)$ & $4(29.14)$ & 28 \\
\hline Maximum classroom height ( $3 \mathrm{~m})$ & $24(71.85)$ & $4(29.14)$ & 28 \\
\hline Minimum space for each student (3.75-4.5 m) & $24(71.85)$ & $4(29.14)$ & 28 \\
\hline $\begin{array}{l}\begin{array}{l}\text { No disturbance of the assembly hall, laboratory, workshop, sports } \\
\text { venue }\end{array}\end{array}$ & $22(57.78)$ & $2(58.28)$ & 28 \\
\hline Use of maximum natural light & $26(87.92)$ & $2(14.7)$ & 28 \\
\hline Protecting doors and windows with a wire mesh on the outside face & $3(71.10)$ & $25(28.89)$ & 28 \\
\hline Sanitary trash cans & $28(100)$ & $0(0)$ & 28 \\
\hline
\end{tabular}

Table 4. The safety status of laboratories in schools of Khalkhal City

\begin{tabular}{cccc}
\hline Safety facilities & \multicolumn{2}{c}{$\mathbf{N ~ ( \% )}$} & Total \\
\cline { 2 - 4 } Washable floor & Compliance & Noncompliance & 17 \\
\hline Non-slip floor with suitable slope & $17(100)$ & $0(0)$ & 17 \\
\hline Having air conditioner appropriate to its space & $17(100)$ & $3(7.17)$ & 17 \\
\hline Having toilet and liquid soap & $14(3.82)$ & $11(7.64)$ & 17 \\
\hline Existence of safety instructions & $6(3.35)$ & 8 (53) & 17 \\
\hline
\end{tabular}

had a drinking fountain for every 45 students, of which $42.85 \%$ had drinking fountains separated from the toilet. Considering that the provision of safe drinking water is one of the general principles of public health, the quality of drinking water in all schools was reported at a desirable level due to the use of the urban water distribution network which is consistent with the results of Shokri et al. [6], Sarmadi et al. [16], Shabankhani and Abdollahi [17], and Pirzad et al. [18]. This shows the country's attention to this principle. In Adegbenro's study, only 50\% of Nigerian schools had healthy drinking water [19].

Shukri et al. examined 144 schools in Abadan in terms of environmental health and safety. Their results showed that $100 \%$ of the schools had sanitary trash cans and in $76 \%$ of the schools there was one totile for every 40 people [6]. In terms of proper sewage disposal that should meet the standards of school regulations, 100 schools complied with this item, which is consistent with the results of Zazuoli et al. [20]. In the study by Pirzad et al. on comparing the environmental health status of public primary schools in different parts of Isfahan, 77 schools were randomly selected and surveyed. Their results showed that $76.6 \%$ of schools had a standard status, $80.5 \%$ of their classrooms had a favorable situation, $79 \%$ had a favorable situation in terms of collecting and disposing of sewage, and $49 \%$ had clean buffets in accordance with the standards. Moreover, the condition 
of toilets and washbasins and drinking fountains were good, and there was no significant difference in this regard between different areas [18].

Human safety issues during crisis in schools include: placing the feet on the ground or on a proper support, the suitability of the backrest when sitting on a chair, the acceptable weight of a student's bag, non-slipness of stairs and their fencing, non-slipness of the floors of classrooms and hallways, upper-floor window safety protection, no balcony or terrace, safe and secure heating equipment, keeping oil and gas tanks far enough away, having enough fire extinguishers and in the right place, good conditions and right protection of electrical switchboards, switches and sockets, existence of at least two emergency exits with a special sign and an emergency alarm.

In the present study, of 28 schools, 59\% had at least two escape routes for emergencies and $92 \%$ had alarms for emergency use. Schools were at relatively good state in terms of safety measures and emergency conditions which is consistent with the results of Malakootian et al. [21]. In studying the environmental health and safety of schools in Kerman, they reported that the safety of schools in some cases (upper-floor windows with protective fences, safety instructions on heating and cooling devices, conditions of heaters/ radiators/firefighting facilities) were relatively favorable. According to the results, 17 schools in Khalkhal had laboratories, all of which had washable and non-slip floors, while only $47 \%$ had safety use instructions provided in the laboratory. Although the safety status of the schools was acceptable, maintaining the current status and improving it should be considered in the programs.

\section{Conclusion}

The safety and health of students is directly related to the crisis issue in schools, so the first step in developing crisis management programs is to evaluate schools comprehensively and accurately. It was concluded that most schools in Khalkhal City were at moderate level in terms of environmental health and safety and compliance with national school environmental health regulations, which indicates a need for more attention and support for improving their status from the relevant authorities. Given the crisis management approach, it is recommended that all school principals and district administrators use such tools periodically to assess the condition of schools and pay attention to missed points so that an acceptable care environment be provided for all students in schools throughout the country, and to prevent any possible harm to students when facing a crisis in schools.

\section{Ethical Considerations}

\section{Compliance with ethical guidelines}

This research was extracted from an approved research proposal (Code:1.2296).

\section{Funding}

This research did not receive any grant from funding agencies in the public, commercial, or non-profit sectors.

\section{Authors' contributions}

All authors contributed in preparing this article.

\section{Conflict of interest}

The authors declared no conflict of interest.

\section{Acknowledgments}

The authors would like to thank the Deputy for Research of Ardabil University of Medical Sciences for their support in conducting this study.

\section{References}

[1] Mazloomi S, Haghigaht GA, Koulivand Z, Rahmani S, Nourmoradi $\mathrm{H}$. [Investigation on the environmental health status of primary and junior high schools of Abdanan City (Ilam) in 2016 (Persian)]. Journal of Jiroft University of Medical Sciences. 2017; 4(1):153-63. http:/ /journal.jmu.ac.ir/article-1-143-en.html

[2] Paci-Green R, Varchetta A, McFarlane K, Iyer P, Goyeneche M. Comprehensive school safety policy: A global baseline survey. International Journal of Disaster Risk Reduction. 2020; 44:101399. [DOI:10.1016/j.ijdrr.2019.101399]

[3] Miri A, Hami M, Dargahi A, Poursadeghiyan M, Farrokhi M, Ivanbagha R, et al. Study on the awareness of the students of Azad University of Medical Sciences about nutrition and food storing stuff during crisis. Health in Emergencies and Disasters. 2018; 3(2):91-6. [DOI:10.29252/nrip.hdq.3.2.91]

[4] Dargahi A, Bagheri S, Poursadeghiyan M, Hosseini Ahagh M, Farrokhi M. Knowledge and attitudes of students in Khalkhal Medical Sciences Faculty on health actions in emergencies. Health in Emergencies and Disasters. 2017; 3(1):51-6. [DOI:10.29252/nrip.hdq.3.1.51]

[5] Meldrum RC, Jackson DB, Archer R, Ammons-Blanfort C. Perceived school safety, perceived neighborhood safety, and insufficient sleep among adolescents. Sleep Health. 2018; 4(5):429-35. [DOI:10.1016/j.sleh.2018.07.006] [PMID]

[6] Shokri R, Dargahi A, Rezaei S, Valipour A, Zovedavianpoor S, Atafar Z, et al. A comparative study of the environmen- 
tal health and safety of urban and rural schools of Abadan and their compliance with national standards. Journal of Advances in Environmental Health Research. 2018; 6(1):9-16. [DOI:10.22102/JAEHR.2017.100597.1043]

[7] Lyons RA, Delahunty AM, Kraus D, Heaven.M, McCabe M, Allen H, et al. Children's fractures: A population based study. Injury Prevention : Journal of the International Society for Child and Adolescent Injury Prevention. 1999; 5(2):129-32. [DOI:10.1136/ip.5.2.129] [PMID] [PMCID]

[8] Atteberry-Ash B, Kattari SK, Speer SR, Guz S, Kattari L. School safety experiences of high school youth across sexual orientation and gender identity. Children and Youth Services Review. 2019; 104:104403. [DOI:10.1016/j.childyouth.2019.104403]

[9] Zazouli M A, Abadi M H, Yousefi M. [Investigating the Environmental Health and Safety Indices among Schools in Mazandaran Province, Iran (Persian)]. Journal of Health Research in Community. 2015; 1(1):28-34. http://jhc.mazums. ac.ir/article-1-31-en.html

[10] Shirzad Kebria B. [Identifying the main dimensions and components of crisis management in order to offer an appropriate mechanism for high schools in Tehran city (Persian)]. Journal of Educational Administration Research Quartery. 2013; 4(16):85-118.

[11] Mehraein Nazdik Z, Mohammadi M. Comparing Shiraz and Kerman High School Students' Knowledge for an Earthquake Encountering. Health in Emergencies \& Disasters Quarterly (HDQ). 2018; 3(3):167-74. [DOI:10.29252/nrip.hdq.3.3.167]

[12] Maitra A. School accidents to children: Time to act. Journal of Accident \& Emergency Medicine. 1996; 14(4):240-2. [DOI:10.1136/emj.14.4.240] [PMID] [PMCID]

[13] Kumar R, O'Malley PM, Johnston LD. Association between physical environment of secondary schools and student problem behavior: A national study, 2002-2003. Environment and Behavior. 2008;40(4):455-86. [DOI:10.1177/0013916506293987]

[14] Lee A, Cheng FF, Fung Y, St Leger L. Can health promoting schools contribute to the better health and wellbeing of young people? The Hong Kong experience. Journal of Epidemiology \& Community Health. 2006; 60(6):530-6. [DOI:10.1136/ jech.2005.040121] [PMID] [PMCID]

[15] Institute of Standards and Industrial Research of Iran. School hygien (No: 2086). $1^{\text {st }}$ ed. Institute of Standards and Industrial Research of Iran: Tehran; 2002.

[16] Sarmadi M, Bazrafshan E, Zarei AA, BarjastehAskari F, Jahanara $\mathrm{T}$, Tatatri $\mathrm{M}$. [Investigation of the environmental health and safety status of primary schools in Torbat Heydariyeh City in 2016-2017 (Persian)]. Journal of Torbat Heydariyeh University of Medical Sciences. 2018; 6(2):58-65. http:// jms.thums.ac.ir/article-1-433-en.html

[17] Shabankhani B, Abdollahi F. [Evaluation of hygienic environmental indexes (educational spaces) in village schools of mazandaran province in 2003 (Persian)]. Journal of Mazandaran University of Medical Sciences. 2004; 13(41):98101. http://jmums.mazums.ac.ir/article-1-357-en.html

[18] Pirzadeh A, Sharifirad G, Oruji MA. [Comparison of environmental health in public primary schools in different districts of Isfahan, 2007-2008 (Persian)]. Health System Research. 2011; 6(1):44-9. https:/ / www.sid.ir/FileServer/JF/3001013890107.pdf
[19] Adegbenro CA. Effect of a school health programme on ensuring safe environments for primary school children. The Journal of the Royal Society for the Promotion of Health. 2007; 127(1):29-32. [DOI:10.1177/1466424007073204] [PMID]

[20] Zazuoli MA, Abdi MA, Ghahramani E, Ghorbanian M. [Investigation of environmental indexes of district 1 primary school in Sari, Iran (Persian)]. Iranian Journal of Health and Environment. 2009; 2(3):204-13. http://ijhe.tums.ac.ir/article-1-154-en.html

[21] Malakootian M, Akbari H, Nekoei MM, Parizi A, Nekounam GA. [Investigation of environmental health condition and safety of schools in Kerman in 2007 (Persian)]. Toloo-eBehdasht Journal. 2008; 7(3-4):1-14. https://www.sid.ir/fa/ journal/ViewPaper.aspx?id=127222 
This Page Intentionally Left Blank 